\title{
Ageing, Risk and the EU
}

\author{
Jason L. Powell \\ Faculty of Health \& Life Sciences, Coventry University, Priory Street, CV1 5FB, \\ Coventry, United Kingdom \\ E-mail address: jasonpwll3@gmail.com
}

\section{ABSTRACT}

This article explores the concept of 'risk' in relation to the theoretica stu of old age de welfare in Europe. Ideas related with what has been conceptualised as the 'ris' soviety eck, 19 2) have, it might be argued, become part of the organising ground of how we "ne and pos ne cpersonal' and 'social spaces' in which to grow old. This has startling con uit cross Eur pe. These spaces have served to place the definition of what it means to be an perso shifts from state care to individualised care (Phillipson and Powell, 2004). As Ulri I Beck (1992) ch As, in the conditions of advanced modernity, growing old moves from being a collective to an individual experience and responsibility.

Keywords: Risk; Age; Europe and Spatial Zone

\section{INTRODUCTION}

This article explores co relation to the theoretical study of old age and welfare in Europe. as relate ith what has been conceptualised as the 'risk society' (Beck, 1992) have, it rig argued, ccome part of the organising ground of how we define and position the 'social spaces' in which to grow old. This has startling continuities acr ss Europe. Tho spaces have served to place the definition of what it means to be an old perso shifts from state care to individualised care (Phillipson and Powell, 2004). As Ulr "eck (19 2) claims, in the conditions of advanced modernity, growing old moves being olle cive to an individual experience and responsibility. Further, Anthony Gid ens (1 8) sugg is that old age is a social constructed category shaped in 'late modernity' by

oyd age at sixty-five is a creation, pure and simple, of the welfare state. It is form of welfare dependency much more widespread than any of the dependencies noted by the rightist interpreters of the underclass (1994:170). [And]:- A society that separates older people from the majority in a retirement ghetto cannot be called inclusive' (Giddens, 1998:120).

However, Giddens claims that risk is an important factor in the reflexive shaping of old age. First, it is claimed that traditional responses to risk are no longer appropriate. Second, and a key factor highlighting the point above, European societies are themselves less predictable. Faith in the ability of the State or scientific experts to manage risk on our behalf has therefore 
diminished. Third, people must anticipate and address risk. Whether this is best achieved by collectively sharing the responsibilities that may lead to individualisation. Four, traditional definitions of risk, premised on technical measures, neglect the social construction of these and of the risks themselves. This in turn poses fundamental questions about the way we define old age. By representing risk as a centrally defining discourse of "late modernity" offers a new perspective: it allows the interrogation of how older people are made subjects in Europe (Powell and Phillipson, 2004).

Foremost in European societies with little developed welfare systems the concerns regarding the side effects of a society governed by the concepts of risk and individualication are widely disseminated (Giddens, 1991). Linked to this, neo-liberalism gives th Impro that older people have the capacity to generate their own autonomy and $r$ onsibility indicative of 'consumer culture' (Gilleard and Higgs, 2000) irrespective structur constraints. Similarly, theorists advocating positive ageing pontificate fro 1 a cultura pro ch by focusing on the benefits of neo-liberalism (Gilleard and Higgs, 20 9). Th is par alarly apparent in a move toward neo-liberal discourses of consumerism ic icially ppears to indicate a reallocation of attention from responding to problems uch as 'p rty' cf. Walker, 1981), for example to an attempt to define what it is to alle 'age posic $1 y$ ' in an neoliberal era were older people "have never had it so gogd Gillo and Higgs, 2000). For Gilleard and Higgs (2000) this trend is happening in you culture greatly reconstructs both the formal expectations and personal experienc of later life. Int estingly, Gilleard and Higgs do not see the relevance of risk to the uncerta postmoder times through which older people express their performativity.

Whilst such account is highly idealiatic it does of hlight the critical features of everyday life of older people and the impi on risk. Such an account represents an ideological distortion by not focusing on the ney ations of power across Europe for older people- such neo-conservative-writers o crlook the risk of hardship and poverty in old age Indeed, Alan Walker and Ge 1are aegele (999) convey the critical message that there is a pressing need for governme and her agen cies to respond to changing circumstances of an ageing European popul $n$. . apcan pritical processes have become preoccupied with the fiscal support of the livery of $s$ services to an ageing population as this demographic shift alters the balar e veen thos in work and paying taxes, and those in retirement receiving benefits now consu, health care and other social services. Consumption theorists such as Gillea a and Higgs o o) overlook and underemphasize the risks attached the structural po ioning fold age in Europe.

The hist 1 lessor is this. Throughout the 1980s and 1990s European governments uniform ought intro ace market dynamics into the delivery of services by creating quasimar $^{2}$ ets th rely o nternal commissioning and purchasing by providers. In the United King m ples legislation required that local authorities embark upon a phased progra directed by central government, of compulsory competitive tendering, with the strategy a feasing the role of local authorities and stimulating greater provision of services by the privite sector. This program, like its cousins elsewhere on the continent such as France and Germany, rested on the belief that a competitive market and a mixed economy of welfare inevitably provides services that are better and cheaper than those available through the public sector, the reasoning being that a protected public bureaucracy is capable only of furnishing services that are limited, inflexible, and indeterminate and many users are unable to obtain the services they require. European governments assume that they can put in place a mixed economy of welfare to meet the needs of their populations and to facilitate consumer choice among the various services. However, the introduction of "choice" may in fact reduce the 
number of options available because a reduction in public sector provision may not be matched by the development of a diverse range of service options in the voluntary and private sector (Powell and Phillipson, 2004). Planning is necessary, particularly in light of the demographic changes. The statistical reality that Europe's population must inevitably age because the fertility boom in the late 1950s and early 1960s and the increasing expected average lifespan will greatly increase the number of older persons across the European Union from about 2020 forward.

The spectre of an ageing population necessitates the dismantling of the welfare state and the introduction of a greater degree of reliance on personal financial provision and privately provided care arrangements. These proposals are linked to ideological shifts during tho-latter part of the twentieth century, and the concomitant reassessment of the social cont act be n the state and its population. As a result, "cradle-to-grave" principles of postwar cial plann have been replaced by policies which encourage those with resources to make vision $f$ themselves, with the less well off depending on minimal state suppor. This exc in as serious implications for the workings of EU states, for over time the $j$ res ra will ot the stability and security of health and political structures in all Euro ean atries. Jorder to preserve the basic tenets of intergenerational solidarity and to de top a mo nclue ve society, it will be necessary to find ways in which the views of or ch ople can appropriately represented (Powell and Phillipson, 2004).

Older citizens must have a greater "voice" in services provision. The point made by Walker and political economy of ageing is needed to engender $\mathrm{s}$ what older persons need and the manner in which th society, rather than the current policies that focus a pension arrangements and the provision of social welfare. New policies the requirements of the risk society. The politics of old age is not just ab it lf arm to live with an older population and how to arrange the provision of services, but i. nore about rethinking the nature of European society itself.

Indeed, in contemporar rop in society, risk is a broad concept that extends over a broad range of social practi tha the experiences of older people. Current debates about older people an relationsh to sexuality, crime, national security, food safety, employment and welf re all unders ored by risk (Phillipson, 1998). A recent report by the UN Commission ${ }_{\text {gests }} \mathrm{w}$ in which the security of older people, for example, might be advanced - fro h humanitaria and military strategies through to economic, health and educational tegie Coupled with this, the US Central Intelligence Agency's (CIA) (2004) World Fact BO "ggests at an "ageing population" is a risk to the financial safety of western nation in U. a d F rope.

Such in appro seeks to capture the dimensions of subjectivity within the socialpor $1 \mathrm{c}$ minte hat shape individual lives. This allows reconstructions of logics of action or stru ation behind current neo-liberal self-representations of ageing identity. It could be supposed such constructions enable us to reconstruct the complexity of ageing in social contexts and the influence of, for example, social welfare on these experiences as a ground for risk perception. Importantly, the notion of an ageing society becomes secondary to the emphasis on the way in which families and individuals handle the demands associated with an ageing population. Phillipson and Powell $(2004,33)$ suggest that there are three factors that make risk important to understanding old age:

'First, the globalisation of aging is increasingly recognised. All societies (poor as well as rich) are undergoing similar population transformations (albeit with notable exceptions such as those in countries devastated by the 


\begin{abstract}
AIDS virus). Aging thus becomes simultaneously both a biographical event and one shared with different cultures and societies across the globe. Second, aging experiences are themselves hugely (and increasingly) diverse. Under the guise of the welfare state, growing old was compressed into a fairly limited range of institutions and identities (notably in respect of income and lifestyles). Aging in the post-welfare society, however, has substantially expanded in respect of social opportunities as well as economic inequalities. Third, old age is also being changed by what Beck (1992) describes as the era of reflexive modernization. This may be conceived in terms of how individuals and the lay public exert control and influence on the shape and character of modernity.'
\end{abstract}

The more European societies are modernised, the more older people aruire ability reflect upon the social forces of their existence within the conditions of ri constrain Her ce, we need to understand the major social forces which impinge on a ing its Such oocial forces that create risk associated with ageing implies a breakdown $t \mathrm{~s}$ s a key codernist principle in contemporary society. Hence, the rest of the article s in three ts: y introduce the relevance and breakdown in trust relations; map out the 1 umptions isk society in Europe; and critically engage with old age and examp os traw om social welfarism to consolidate an understanding of the constructedness of oru ase in Eurc

\title{
2. FROM TRUST TO RISK
}

There are increasing attempts to conce the notion of 'trust' in social theory as a pivotal dimension of European society (Gid ens 1s, However, the early statement that 'social science research on trust hacmroduced good deal of conceptual confusion regarding the meaning of trust and its pla e in cial life (Lewis and Weigert 1985 quoted in Powell, $2005,104)$ seems to be still var. speg allv as applied to aging studies. Trust is on the one hand incompatible with comple no e or mossibility and probability of future events, and on the other hand with phatic be when the anticipation of disappointment is excluded. Someone who trusts as a pectation directed to an event. The expectations are based on the ground of incom know about the probability and incomplete control about the occurrence of the event. Trust is relevance for action and has consequences for the trusting agent if trus confy ar disappointed. Thus, trust is connected with risk (Giddens, 1991).

Up to no ere hay been few attempts to work out a systematic scheme of different forms st in $\mathrm{s}$ reen older people and individuals, institutions or policies that impinge on thei adent perfor nce. Social trust tends to be high among older people who believe that then by high (Walker and Naegele 1999). Since the erosion of public trust in institu such as, for example, the Brown government in UK with it losing 25 million people's /details and identity or the $£ 25$ billion financial loss of UK bank Northern Rock in late $200 /$ or the recently maligned 'credit crunch', 'trust' has attracted more and more attention.

Molling (2001) distinguishes between trust in contracts between people and State (such as pension provision), trust in friendships across intergenerational lines, trust in love and relationships and trust in foreign issues (associated with national identity across the EU). However, sociological theories which suppose a general change in modernity (cf. Beck, 1992) assume that with the erosion of traditional institutions and scientific knowledge trust becomes an issue more often produced actively by individuals than institutionally guaranteed. 
There are a number of implications of risk perception and risk taking that indicates: trust is much easier to destroy than to built; if trust is once undermined it is more difficult to restore it; familiarity with a place, a situation or a person produces trust; persons will develop trust if a person or situation has ascriptive characteristics positively valued. Trust seems to be something that is produced individually by experience and over time and cannot be immediately and with purpose be produced by European governments without dialogical interaction with older people on issues affecting their lifestyles and life-chances such as care, pensions, employment and political representation in the EU (Walker and Naeghele, 2000).

Though as Giddens (1991) stresses risk is the feature of a society shifting its emmhasis away from trust on traditional ties and social values. How risks are perceived an rormu d as a breakdown in trust reflects the essentially discursive practices of politic nd power European society. The ability to control and manage perceptions about moral in tions of pervasive governmental rationality may be part of an understanding of ri $\mathrm{K}$.

\section{BECK AND THE 'RISK SOCIETY' THESIS}

The concept of risk has come to assume accelerating minc in sociological writings of Ulrich Beck. Beck (1992) claims that modernizati ns the sy beome an agent via processes of individualization which they both se as indicative o/ neo-liberalism; they advocate that the self become less constrained by t ditional gro $p$ identities and institutions but more constraint by the dynamics of markets our mar ets, consumer-markets) and secondary institutions, and becomes therefare a projo reflexively worked on in the context of a globalised world. As we see th onment of this the new global order, some risks such as those caused by hazardous ind trie, insferred away from the developed countries to the Third world. Thus while Beck es risk society as a catastrophic society, what we are seeing is the transference of a ain risk through aversion and management which in turn include a reorganisation wer and auth rity' (Beck, 1982:4)

Beck acknowledges to soups are more affected than others by the distribution and growth risks, ano ese differences may be structured through inequalities of class and social pe titio The disady ntaged have fewer opportunities to avoid risk because of their lack of recul es con red with the advantaged. By contrast, the wealthy to a degree (income, powe or education), 1 purchase safety and freedom from risk (Beck 1992: 33). However, it the ge tion and the constellations of the risks, which are unknown, and thus risk affects tho no have roduced or profited from them, breaking down the previous social and ges hic bu dari s evident in modern societies.

Beck 1992), a a dhat the 'former colonies' of the western world are soon becoming the te the world for toxic and nuclear wastes produced by more privileged counth Risks nave become more and more difficult to calculate and control. Hence it can be argued $y$ Risks often affect both the wealthy and poor alike: "poverty is hierarchic and smog is democratic' (Beck, 1992: 36). At the same time, because of the degree of interdependence of the highly specialised agents of modernisation in business, agriculture, the law and politics, there is no single agent responsible for any risk: 'there is a general complicity, and the complicity is matched by a general lack of responsibility. Everyone is cause and effect' $(: 33)$ and so 'perpetrator and victim become identical' (:38) in a consuming society. It is this immateriality and invisibility of the threats that saturate the 'risk society' making it harder to identify the offender of global risk. Beck (1992), argues that this fundamentally poses the second challenge for analyses of these socially constituted industrial phenomena: interpretation 
becomes inherently a matter of perspective and hence political. Politicians constantly invoke science in their attempts to persuade the public that their policies and products are safe. The inescapability of interpretation makes risks infinitely malleable and, as Beck (1992:23) insists, 'open to social definition and construction'. This in turn put those in a position to define (and /or legitimate) risks - the mass media, scientists, politicians and the legal profession - in key social positions (Phillipson and Powell, 2004).

Ulrich Beck (1996) makes the point that risk is not an option which could be chosen or rejected in the course of political debate' (1996:28). Instead this is an inescapable product and structural condition of advance industrialisation of where we produce the hazards of that system, in Beck's words (1996:31)'undermine and/or cancel the established safet syste the provident state's existing risk calculation'. Beck (1996) further exemplifi this point examining contemporary hazards associated with nuclear power, cheminal $\mathrm{P}$ ution at genetic engineering and bio technology that cannot be limited or containe to particu spar es, and that which cannot be grasped through the rules of causality, and onnot safeg ided, compensated or insured against. They are therefore 'glocal': both lo $1 \mathrm{a}$. 0 bal. R $\mathrm{K}$ society is thus 'European risk society' and risks affect a European citiz sship. Th 'esti ning of the outcomes of modernity in terms of their production of $\mathrm{r}$ an outc of reflexive modernisation. An awareness of risk, therefore, is heighten at the rel of the everyday.

In Europe, risk, in its purely technical meaning um to rely $\mathrm{u}_{\mathrm{u}}$ conditions in which the probability estimates of an event are able to be $\mathrm{k}$ own or knowable. This has the effect of paralysing action and bringing insurance systems at promised to cover eventualities into chaos. In Great Britain for example, the welfare sta an insurz ace system that promised to cater for people from cradle to the grave, is umable to sus promise for future generations. The welfare system as a system of social ins is beginning to lose its legitimacy with the rise of private health insurance. In the USA, 0 opulation do not have private health insurance (Powell and Phillipson, 2004).

Scientists have lost their a anor in relat on to risk assessments most evidently seen in the collapse of endowment a ertaj nension funds. Scientific calculations are challenged more and more by political yps actur. (Beck 1995:125-6). The nature of such hazards, therefore, returns the co ept of ris the pre-modern notion of 'incalcuble insecurities'. In common with such b zar they 'und cut the social logic of risk calculation and provision' (Beck 1995:77). F bick, th risk may be defined as 'systematic way of dealing with hazards and insecurities induced and in aced by modernisation itself' (Beck 1991:21).

If this aht be ppening to older people, what are the implications? Two developments seem to be res, sible fo the growing risk awareness in modern industrialised societies in Europe thow their respective contribution is contested. The new awareness of the limits of th tech cal and mathematical/statistical calculation of risk would cause an increase of con s $y$ dino rational controllability of an uncertain future (Beck 1992, Bonß 1995). Furthe re, the sustained endeavour to apply a new liberal style of governing modern societies would in angly shift the responsibility of the management of risks and uncertainties from the state to the individual. Socio-demographic changes as well as shifts in governance contribute to the perception of risk and uncertainty regarding old age in two ways: First, they promote the understanding of risk and uncertainty in old age and second, they suggest to perceive age as risky and uncertain.

In order to approach the concept of risk and old age it is suggested that by conceptualising risk in a broader framework of (un-)certainty (Zinn 2005) where risk is seen as a specific strategy to produce certainty in order to enable to act. Risk appears then as a certainty construction - a specific way to produce the necessary certainty as a prerequisite for action 
(Zinn 2004). Thereby the future becomes accessible for planning and action. In order to work on itself, the 'self' or at least according to Beck $(1992,181)$ relates to self-political rationalities and risk: 'risks become the motor of self-politicization of modernity in industrial society'. One element of the 'motor' of self-politicisation is how successful neo-liberalism has been in fashioning common sense discourses around its political rhetoric. Jurgen Habermas (1986, 1314) claims what we are witnessing is a 'completely altered relationship between autonomous and self-organized public spheres on the one hand, and sub-systems steered by money and administrative power on the other'. Self-autonomization coupled with administrative power is indicative of 'risk': neo-liberal features of social policy for older people. Older people lixing in neo-liberal EU societies have therefore moved towards a greater awareness of 1 ISK an re forced to deal with risks on an everyday basis: 'Everyone is caught up in defe ve battles various types anticipating the hostile substances in one's manner of living nd a 'g' (Bec 1994: 45). The media for their part have taken up warnings of ex, erts abou in nd communicate them to their mass publics in the EU.

There is an ambivalence at the heart of Europe: on the one $b$, 1 peopl are to be 'managed' by other administrative powers such as professional experts in oderr sty (Powell and Phillipson, 2004); on the other hand, older people are left oc ern thems cs. This moral idea of freedom and responsibility is involved in the mo ern on to govern European societies (Foucault 1991) but is determined by the lip everyda ife in socioculturally different circumstances (Bourdieu 1979) within a Isk society' (Begk, 1992). The tension between ideal and socio-cultural structured life cons tutes the bat leground of the disputes on the governance of old age. These, along with tie tween g nerations, created a social, economic and moral space within which grewing numb der people could be channelled and contained. For example, for a period or ors or more, moving older people into the zone of retirement and the welfare state, held at by anderlying issue of securing a place and identity for ageing within the framework o in advanced capitalist society. The meaning of later life was, temporarily at leas, $\mathrm{co}$ ructed o t of a modernist vision where retirement and welfare were viewed as natur?

\section{THE GOVERNA AC F UNCE, CAINTY IN WELFARE AND OLD AGE}

The gove nance of old ag Minally developed and was closely linked to the creation of a social secy $\mathrm{v}$ sys and the welfare state. The idea of prudence and self-responsibility among the wo class as expressed through such institutions as the friendly society and the rey bun solety and promoted both political quiescence and the stability needed to sure ady gro $\mathrm{c}$ in the later half of the $19^{\text {th }}$ century (Dean 1999). This system was sup the modern welfare state (. Tld 1986, O’Malley 2000). The provision for old age was originally not central, because a end of the $19^{\text {th }}$ century most people did not reach the age of 70 to claim a pension and live thy ough this last phase of their life without having to work. The original concept was to save the worker and its family in case of death or disablement of the breadwinner.

The strategies of risk-management by means of insurance were understood as sharing them between all insured people, which should be in principle as much as possible. But this fundamental concept has changed recently as part of a general change in the idea of insurance as well as the government of citizens. The responsibility of the state and thereby the risks are given back to the public. As Baker and Simon $(2002,4)$ recently pointed out, "...private pensions, annuities, and life insurance are engaged in an historic shift of investment risk from 
broad pools (the classic structure of risk spreading through insurance) to individual (middleclass) consumers and employees in return for the possibility of greater return."

The understanding of the individual as a self-responsible actor as given for granted underestimates the various resources and life experiences different people possess. The strategies to cope with risk and uncertainty in the life course are rather oriented on the circumstances of everyday life, personal values and life experiences that relate to selfresponsibility. Governmental programmes are mainly developed against the background of the model of a self-responsible actor, and increasingly address people with significant lack of cultural and economic resources as self-reflexive and rational actors (Taylor-Goob-2006). Although this concept might be generally helpful in order to formulate political progran s they regularly fail because of this assumption.

The governmental constructions of risks and old age converge in thenotic f ration acting old people. It does conceptually ignore that the ability to be auton mous and iona is not a question of context-independent (free) will or something wha s just iven, it is provided by context factors as well as biographical experiences the ex ectations regarding the future. Thereby accumulated "local knowledge" (y ynne 1) pro' aces logics of how to act best in an uncertain context (e.g. Zinn 2005) policy of the government as well. This is not only important when peon are $\partial_{\text {, }}$ ut in earlier life phases when they have to deal with their expectations regarding oru ge and ho take precautionary measures. The unequal resources available, the unrefl cted routines and needs and execution of everyday life shape what is the basis to act in 'old ge' (Powell and Phillipson, 2004).

The extrication of these actions can be traced to least thre types of crisis affecting the management of aging populations in the las quarter entieth century across Europe: economic, social and cultural. The econ imension has been well-rehearsed, with successive crises from the mid-1970s onward un $\mathrm{cm}$ ig , first, the goal of full employment (and hence destabilising retirement) and, s cond, the fiscal basis of the welfare state (accelerated with the onset of a p Ivat tion fro the 1980s onwards) (Estes, 2001).

However we are neither rovic ent state and or a providing state. The dialectic of risk and social insurance syster fo fratum ave failed to address or predict the increase in longevity, the blurring $g$ the life-co and the growing trend for smaller families. What we are beginning to see $\mathrm{ccu}$, th entry nd immersion in to a risk society is the fracturing of insurance social stans tha failed to make accurate predictions in the EU (Powell and Phillipson, 200/). This has led those who can afford to invest in various insurance policies ways of min zing $y$ that may befall them in times, when illness occurs, unemployment (i.e: mortgage proto 1), deat which are all sold on the basis of what may happen in the future. The sh is th at elders from lower socio-economic groups who without insurance will oe cat ht with the widening fractures appearing in the welfare state. Old age is also bein. har describes as the era of reflexive modernization. This may be con ed in terms of how individuals and the lay public exert control and influence on the shape and acter of Europe.

\section{CONCLUSIONS}

How do we define "old age"? Is it a stage in life defined by a particular age or event such as retirement, is it determined by physical characteristics and the loss of independence, or is it an artifact of social structures? Indeed, is it helpful to categorize people as being "old" at all, as opposed to being "disadvantaged" or "dependent"? It may be inaccurate to expect older people 
to see themselves as a category with particular health needs and wants. Hence, the key task is to analyse the interplay between social policy and the lives of individuals, families or groups and communities. The expectation of negative events in the future and the different ways of how to respond to such expectations is central for the sociological approach to risk and uncertainty (Zinn 2004). Part of this reflexive response is the importance of recognising selfsubjective dimensions of emotions, trust, biographical knowledge and resources (Zinn 2005) that impinge on the existential shaping old age. Hence, our discussion provides a critical narrative to the importance to the study of old age and welfarism in Europe. It has become commonplace for academics and practitioners to explore, develop and apply an assortmant of social science perspectives on risk. In a post 9/11 world, questions around $\mathrm{sK}$ anc $\mathrm{k}$ management have become ever more pertinent, leading to reflections on a num of differ levels about 'ontological security'.

We are left with two questions: how do older people manage their ense of wo ein in a world in which less and less can be taken for granted? To what ey nt doe the sp re of global risks interplay with more routine insecurities which reach to 11 ary text of dayto-day life of older people? There is an urgency to reflect on the question un erstand the subject positioning of older people in a European society th th haracteris oy increasing uncertainty and risk. Indeed, it is perhaps emblematic of con npora vestern culture that each of the technologies identified above offers the promise an ape fron then an understanding of aging identity. Those who do not co form to the utopia 1 dream appear to have been shunted into a non -participative discourse, bc nded by pro essional surveillance or the more palatable yet closely related discourse of " vitoring" In both cases, it could be suggested that a discourse on dependency ha been sup cd, and in some cases replaced, by a discourse on risk. The risk of giving in th ing body, the risk of thereby being excluded from one's retirement community, the risk of ein for to maintain a consumer lifestyle, the risk of being excluded from porticipatio through incapacity that has been externally assessed, the risk of being abuse ', the k of col rol being taken out of one's hands, the risk of tokenism in partnership, and $\mathrm{t}^{1}$ isk o losing reources.

\section{References}

Professor Jason L. Powil BA (Hon My, Ph.D, FRSA is Professor of Social Gerontology and Associate Dean of Faculty of Her a and ife Sciences $\leadsto$ University of Coventry. He holds an Honorary Fellowship at University of Liverpool; rary a 1 at Australia-Asia Research and Education Foundation at Tasmania University; Visiting Research $\mathrm{ow}$ at $\mathrm{Ox}$ d; and recently invited as Visiting Scholar at Harvard University. He has been Visiting ssor in ada, S, Australia, Africa and Jordan. He was nominated and elected to Fellowship of the Butsh al Socic Arts (FRSA) in recognition of his research. He has strong interests in social theory, ag powe and identi $\mathrm{s}$. He is author of Social Theory and Ageing (2006) which was part of Charles Lemert's distins cial Formations' book series, Rowman and Littlefield: New York.

[1] Adam B., Beck U., Joost Van L. (2002). The Risk Society and Beyond: Critical Issues for Social Theory, London: Sage.

[2] Adams J. (1995). Risk. London: UCL Press.

[3] Arber S., Attias-Donfut C. (2000). The Myth of Generational Conflict. London: Routledge. 
[4] Baker T., Simon J. (2002). Embracing Risk. S. 1-32 in: Baker, Tom, Jonathan Simon (Hg.): Embracing risk: the changing culture of insurance and responsibility. Chicago: University of Chicago Press.

[5] Bauman Z. (1992). Intimations of Postmodernity. London: Routledge \& Kegan Paul.

[6] Beck U. (1986). Riskogesellschaft: Auf dem Weg in eine andere Moderne. Franfurt am Main: Suhrkamp Verlag.

[7] Beck U. (1992b). Risk Society: Towards a New Modernity, London: Sage.

[8] Beck U. (1994). The Reinvention of Politics: Towards a Theory of Reflexive Modernization in U. Beck, A. Giddens and S. Lash, Reflexive Modernisati Politics, Tradition and Aesthetics in the Modern Social Order. Cambridge Polity Pro

[9] Beck U. (1995). Ecological Politics in the Age of Risk, Cambridge olity Pres

[10] Beck U. (1996). 'Risk Society and the Provident State', in S. Kas B. SCerzyî ki and B. Wynne (eds), Risk Environment and Modernity: Toward anew logy. Jondon, Sage.

[11] Beck U., Giddens A., Lash S. (1994). Reflexive Mode isatio Oolitics, Tradition and Aesthetics in the Modern Social Order. Cambridg ronty Press.

[12] Beck U. (2001). World Risk Society, London: blity Press.

[13] Best F. (1980). Flexible Life Scheduling. New k: Praege.

[14] Bonss W. (1995). Vom Risiko: Unsich woit und Omo wheit in der Moderne. Hamburg: Hamburger Edition.

[15] Bonß W. (1997). Die gesellschaftliche K struktion von Sicherheit. S. 21-41 in: Lippert, E., A. Prüfert und G. Wacht s.): Sic, rheit in der unsicheren Gesellscahft. Opladen: Westdeutscher rlag.

[16] Bonss W., Zinn J., S arame in 56(2/J) (2005) 79-98.

[17] Castel R. (1991) A Dangero éss to Risk in G. Burchell, C. Gordon and P. Miller (eds), The Fouc ult E. Studies in Governmentality. London: Harvester / Wheatsher. $281-298$.

[18] Caplan (eds) 900). Risk Revisited, London: Pluto Press.

[19] Canlan P. P0). Ri Revisited - Introduction in P. Caplan (eds) Risk Revisited, Con n: Plut os.

[20 Capla 1 P. (2000). 'Eating British Beef with Confidence': A Consideration of Responses to BSE in Britain', in P. Caplan (eds) Risk Revisited, London: Pli. Press.

[21] Doug as M., Wildavsky A. (1983). Risk and Culture. Berkeley: University of California Press.

[22] Estes C., Associates, (2001). Social Policy and Aging. Thousand Oaks: Sage Books.

[23] Ewald F. (1993). Two infinities of risk in B. Massumi (eds), The Politics of Everyday Fear. Minneapolis, Minnesota: University of Minnesota Press.

[24] Giddens A. (1990). The Consequences of Modernity. Oxford: Polity Press. 
[25] Giddens A. (1991). Modernity and Self-Identity: Self and Society in the Late-Modern Age. Cambridge: Polity.

[26] Giddens A. (1998). The Third Way; The Renewal of Social democracy_Cambridge, Polity Press.

[27] Gilleard C., Higgs P. (2000). Cultures of Ageing: self, citizen and the body. London: Prentice-Hall.

[28] Kasperson R. E. (2005). Introduction and Overview. In: J. X Kasperson, and R. E Kasperson: The Social Contours of Risk. Volume I: Publics, Risk Communicat; Social Amplification of Risk. London - Sterling, VA: Earthscan, pp. 1-16.

[29] Klein N. (2001). No Logo in a Branded World. New York, Flamingo Pres

[30] Krohn W., Krücken G. (1993). Riskante Technologien: Reflexion y d Regulat Frankfurt a. M.: Suhrkamp.

[31] Latour B., Woolgar S. (1986). Laboratory life: the construc or of su tific fo ts. Princeton, N.J: Princeton University Press.

[32] Latour B. (1993). We have never been modern. Cambr ge, - s: Harva d University Press.

[33] Leonard P. (1997). Postmodern Welfare. Lond h: Sage.

[34] Loewenstein G., E. Weber, C. Hsee, N. Welch, sychologichl Bulletin 127(2) (2001) 267-86.

[35] Lowe R. (1993). The Welfare State in 4 cince 1945. London: Macmillan.

[36] Luhmann N. (1989). Ecological Commu, ic ion. Anicago: University of Chicago Press.

[37] Luhmann N. (1993). Risk: Non logical heory. Berlin / New York: de Gruyter.

[38] Lupton D. (1999). Risk ton buutledge.

[39] Luhmann N. (1993 Risk: A iological Theory. New York: Aldine de Gruyter.

[40] Reddy S. (1996 Cla to Expe $/$ Knowledge and the Subversion of Democracy: The Triumph of skover rtainty in Economy and Society, 25(2); 222-54.

[41] Macnicc J. (19 8). The Po atics of Retirement in Britain, 1878-1948. Cambridge: Cambri Un versit Press.

[42] O., b Vynn, Risk Analysis 9 (1989) 141-145.

[42 Philli son C. (1) 98). The social construction of retirement: perspectives from critical Aitical economy. In M. Minkler and C. Estes, Critical Gerontology:

$P_{a}$ ectives from Political and Moral Economy. New York: Baywood.

[44] Philliy son C., Powell J. L. (2004). 'Risk, Social Welfare and Old Age' article in Tulle, E (Ed.) Old Age and Human Agency, Nova Science Publishers.

[45] Powell J. L. (2005). Social Theory and Aging, Rowman and Littlefield: New York.

[46] Powell Jason L., Wahidin, A., Journal of Societal and Social Policy 3(1) (2004) 37-55.

[47] Slovic P., Risk Analysis 19(4) (1999) 689-701. 
[48] Slovic P., Finucane M., Peters E., MacGregor D. (2002). Risk as analysis and risk as feelings. Some thoughts about affect, reason, risk, and rationality. (Annual Meeting of the Society for Risk Analysis, New Orleans, Louisiana, December 10, 2002)

[49] Stearns P. (1977). Old Age in European Society: The Cast of France. London: Croom Helm.

[50] Thane P. (2000). Old Age in English History: Past Experiences, Present Issues. Oxford: Oxford University Press.

[51] Townsend P., Wedderburn D. (1965). The Aged in the Welfare State. London:

[52] Townsend P., Ageing and Society 1(1) (1981) 5-28.

[53] Tversky A., D. Kahneman, Science 185 (1974) 1127-1131.

[54] Tulloch J., Lupton D. (2003). Risk and Everyday Life, London: S ge.

[55] Vincent J. (1995). Inequality of Old Age. London: UCL Pres

[56] Vincent J., 1999: Politics, Power and Old Age. Buckingb Open U

[57] Virilio P. (1983), Pure War, New York: Semiotext

[58] Walker A., Naegele (1999). The Politics of Old ge in Europe, M on Keynes: OUP.

[59] Wynne B. (1987). Risk Management and Haza ous Waste. Berlin: Springer.

[60] Zinn J. O., Social Theory \& Health 2 (2004) 19

[61] Zinn J. O., Health, Risk \& Society 7(1) 1-9.

[62] Zinn J. O., Taylor-Gooby P. (2006). The haterro of (managing) new risks and uncertainties. In: P. Taylor-Gory, and J. Zinn,(Eds.): Risk in Social Science. Oxford: Oxford University Press.

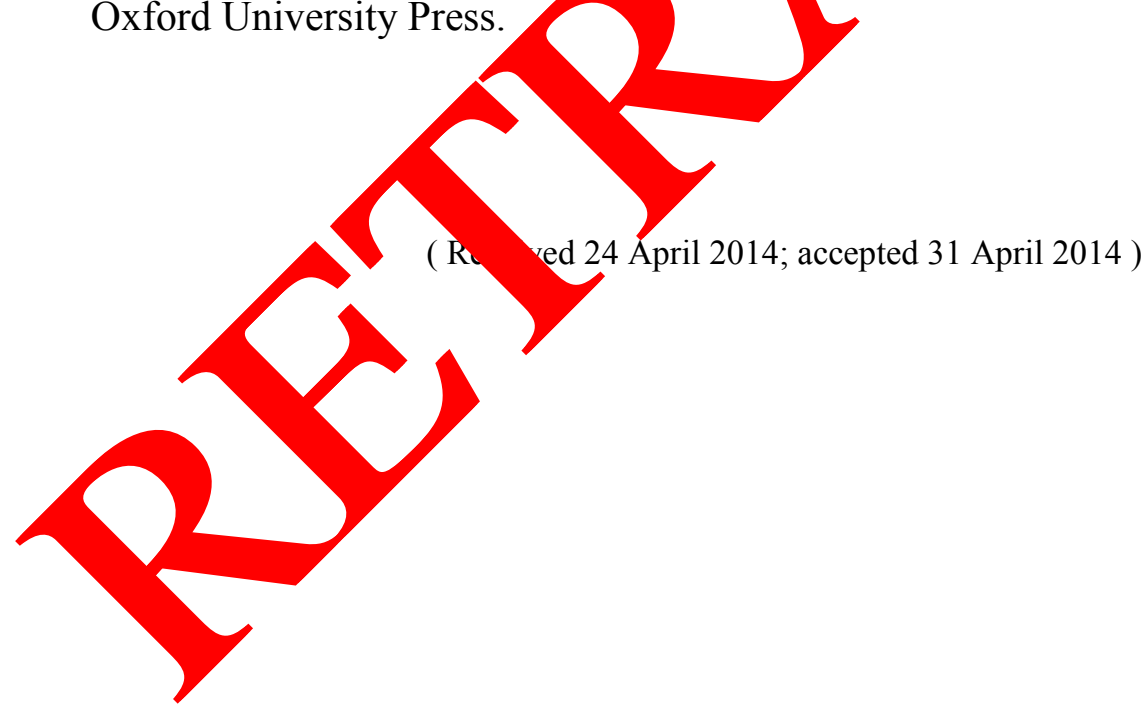

